\title{
CLINICAL AND DEMOGRAPHIC STUDY ON OPEN FRACTURES CAUSED BY MOTORCYCLE TRAFFIC ACCIDENTS
}

\author{
Marcos Almeida Matos ${ }^{1}$, Júlia Milena do Nascimento ${ }^{2}$, Bruno Vieira Pinto da Silva ${ }^{2}$
} \begin{abstract}
Objective: To assess socio-demographic characteristics of individuals that suffered open fractures caused by motorcycle traffic accident and evaluate infection rate in search of associated risk factors. Methods: A retrospective study comprising 81 patients with open fractures caused by motorcycle accidents was carried out. Clinic and socio-demographic features were collected from patients' records. Comparison between infected and non-infected patients was performed to find out which variables were possibly associated to this complication. Results: Patients were mostly young adults (mean 32.9 years old), of the masculine gender (83.9\%), single $(60.5 \%)$, from the country side $(40.7 \%)$, mostly presenting tibial open fractures (48.2\%). Fractures type IIIA and
\end{abstract}

type IIIB were the most prevalent lesions $(68,8 \%)$, and soft tissue damage graded as I and II were the most frequent (64.62\%). Infection was present in $23.7 \%$ of the patients and it was associated to age higher than 40 years old $(p=0.011)$, to time delay from trauma to first surgical procedure longer than 24 hours $(p=0,012)$, and also to soft tissue damage extent $(p=0.001)$. Conclusions: Patients with open fractures caused by motorcycle traffic accident were mostly young single men, coming from the state capital and presented severe tibial open fractures, which $23.7 \%$ of the cases progressed to infection. Level of Evidence III, Retrospective Comparative Study.

Keywords: Fractures, open. Accidents, traffic. Motorcycles. Infection.

Citation: Matos MA, Nascimento JM, Silva BVP. Clinical and demographic study on open fractures caused by motorcycle traffic accidents. Acta Ortop Bras. [online]. 2014;22(4):214-8. Available from URL: http://www.scielo.br/aob.

\section{INTRODUCTION}

Motorcycle is an agile and low cost vehicle which number has been increasing in large cities. For this reason, traffic accidents involving motorcycles have shown significant increase in the last decade. ${ }^{1}$ Motorcycle drivers are also more exposed to accidents and traumas due to the characteristics of this type of vehicle and the lack of physical protection to motorcyclists. ${ }^{2}$

In Brazil, in 1997, 40,000 accidents involving two-wheelers occurred, with 24,000 deaths. ${ }^{3}$ In 1998, 15,232 motorcyclists, victims of traffic accidents, were hospitalized, and in 2004 this number was 27,388 , a $79.8 \%$ increase. ${ }^{3}$ Data from 2006 show that $33.7 \%$ of hospitalizations due to traffic accident in public hospitals in Brazil occurred due to pedestrians running over, while $28.2 \%$ were due to motorcycles accidents. ${ }^{4}$ in the Northeastern region of Brazil , for example, the leading cause of hospitalization is due to running over (41.6\%), followed by motorcycle accidents (24.6\%) and unspecified vehicle accidents (23\%). ${ }^{5}$

Accidents involving motorcycles are traumas associated with considerable speed and energy and usually produce high morbidity and mortality. In these accidents, the constant presence of open fractures contributes to the high demand for hospital admissions. ${ }^{6,7}$ In this type of fracture usually there is extensive injury to soft tissues and bone devascularization, and large contamination of the fracture site. ${ }^{7}$ To prevent the emergence of infection in these cases is the primary treatment goal, considering that the superposition to infection worsens the prognosis, causing greater human suffering associated with high economic costs. ${ }^{6,7}$

Despite these data, open fractures originating from motorcycle accidents are still poorly studied and socio-demographic and clinical data in this respect are very scarce in the Brazilian scientific literature. ${ }^{8}$ Clinical and epidemiological data regarding fractures affecting motorcycle drivers are needed for planning protocols of orthopedics care services in large hospital that provide this type of assistance.

The aim of this study is to evaluate the socio-demographic profile of individuals who suffer fractures due to motorcycle accidents and assess the outcome infection seeking to identify associated risk factors.

\section{All the authors declare that there is no potential conflict of interest referring to this article.}

\footnotetext{
1. Escola Bahiana de Medicina e Saúde Pública, Salvador, BA, Brazil

2. Hospital Geral Roberto Santos, Salvador, BA, Brazil

Work developed at Escola Bahiana de Medicina e Saúde Pública and Hospital Geral Roberto Santos, Salvador, BA, Brazil Correspondence: Rua da Ilha, 378, Itapuã, 41620-620, Salvador, Bahia, Brazil. malmeidamatos@hotmail.com
} 


\section{PATIENTS AND METHODS}

A cross-sectional descriptive analytical study was undertaken, based on clinical data of the Orthopedics Ward at Hospital Geral Roberto Santos (HGRS), located in the city of Salvador, Bahia, Brazil, which provides services to patients from the Unified Health System (SUS) of the city and all the State. The sample was of non-probabilistic sequential type, consisting of 81 patients who suffered fractures by motorcycle accidents who were admitted for surgical treatment from May to December 2009. The study protocol was approved by the Medical Board of Hospital Geral Roberto Santos and by the Ethics Research Committee of Escola Bahiana de Medicina e Saúde Publica de Salvador, BA, Brazil.

All inpatients aged eight years or older, presenting fractures, admitted via HGRS emergency room and also those from other hospitals in the network that reached the Orthopedic Service via Central Estadual de Regulação were included in the study. There were excluded from this study closed fractures, open fractures of the axial skeleton (face, skull, thorax), and patients who did not remain in the hospital for at least one day after the initial procedure, either by death or by immediate transfer.

The Orthopedic Service of HGRS utilizes a standardized case report form for the evaluation of orthopedic patients which is attached to the records. All patient data were removed from this individual clinical record, which states: bed number, name, date of admission, registration number, marital status, gender, date of birth, weight, height, nationality, origin, date and time of trauma and the first surgical debridement, type of accident, initial treatment, fixation, suture, comorbidities, complications, diagnosis of fracture, fracture classification and discharge date. These data were collected by the orthopedist at service.

All patients were treated according to the standard protocol already established in the Department of Orthopedics, which includes initial evaluation with as prompt as possible surgical debridement and thorough washing with approximately ten liters of saline. During the surgical procedure, the fracture is stabilized according to clinical criteria by the orthopedist on duty, preferable with internal fixation for Gustillo types I and II fractures and external fixation for other fractures or those with more than 12 hours delay to initial treatment. After this immediate management, the patient is referred for continuing care on the ward.

Variables extracted and evaluated were: age (age 40, younger and older than 40 years old), gender (male and female), marital status (single, married), origin (Salvador metropolitan area and country side), affected bone (tibia/fibula, radio/ulna, foot/ankle /heel and other sites), time of exposure of the fracture, and time elapsed between trauma and the therapeutic approach. Data about comorbidities such as hypertension, diabetes, alcoholism and smoking were also collected.

The infection (outcome variable) was identified based on clinical and laboratory findings, according to the criteria of early infection within a two week interval proposed by Willenegger and Roth. ${ }^{9}$ This means that the lesion was considered to be infected if the wound had any aspect of superficial or deep infection with or without fever, leukocytosis and elevated erythrocyte sedimentation rate (ESR)..$^{9,10}$ In order to verify this outcome, the patients were assessed during hospitalization and after two weeks follow up, regardless hospital dismissal.
The severity of soft tissue involvement was assessed by criteria from Oestern and Tscherne; ${ }^{11}$ the severity of the open fracture was assessed using the criteria of Gustillo and Anderson ${ }^{12}$ and severity of bone injury was accessed by the criteria of AO classification. ${ }^{13}$ The classification of Gustillo and Anderson ${ }^{12}$ for open fractures, established in 1976, is currently the most used in the orthopedic literature. Briefly, in this classification type I fractures are those considered of minimal severity; type II lesions are of moderate severity; and type III fractures are the most severe.

The classification and Oestern and Tscherne ${ }^{11}$ for soft tissue injury in open fractures is divided into four groups. Grade I lesions have minimal soft tissue injury; in grade II there is skin tear and simultaneous circumscribed contusion with moderate soft tissue damage; in grade III injuries are severe, with eventual neurovascular compromise possible and ischemia, with installed or possible compartment syndrome; grade IV injuries present partial or complete traumatic amputation with vascular injury requiring repair for limb viability.

AO classification ${ }^{13}$ assesses the impairment of bone fracture based on an alpha-numeric system in which the initial numbers represent the bone and its affected part, the letters represent the configuration of the fracture, and the final numbers refer to the complexity of fragmentation. This classification rules, globally, seriousness and energy involved in trauma.

For variables evaluation purposes, it was necessary to regroup some variables based on the number of individuals in each subgroup. Thus, data referring to age, gender, marital status, origin, and most affected bone were recorded. The exposure time was divided into three groups: less than, equal to or greater than 24 hours. Regarding the classification of Gustillo and Anderson, ${ }^{12}$ patients were divided into two groups: patients with open fractures grade I and grade II; and patients with fractures grades IIIA, IIIB and IIIC. In the classification by Oestern and Tscherne ${ }^{11}$ groups classified as grades I and II were compared to groups classified as III and IV. In the AO classification ${ }^{13}$ patients were classified as A, B and C. Finally, considering the fixation used in the treatment of fractures, patients were divided into three groups: external fixation, cast immobilization and those treated with internal fixation.

Patients who developed infection were counted and compared to those who did not have infection with the aim of comparing the clinical and socio-demographic variables of the two groups. This comparison was performed to determine which characteristics were associated with the prognosis of infection and could possibly act as risk factors for this dreadful outcome.

Data were presented in frequency distribution tables for discrete variables and presented as mean and standard deviation for continuous variables. For analysis of risk factors associated with infection, the two groups (with and without infection) were compared using the chi-square test for discrete variables and the Student $t$ test for continuous variables. The value of 0.05 was used as level of significance in all tests.

\section{RESULTS}

The sample totaled 81 patients, 68 male (84\%) and 13 female $(16 \%)$. The mean age was 32.9 years old ( \pm 12.5$)$. Sixty patients (77\%) were concentrated in the younger than 40 years old age group. The majority of the sample consisted of single 
individuals (60.5\%), from the Capital city and metropolitan area, $47(58 \%)$, mostly alcoholics (49.4\%) and suffering from fractures in the lower limbs (tibia/fibula). (Table 1)

The exposure time of the fractures, i.e., the time elapsed between the accident and the onset of surgical treatment was on average 27.9 hours $( \pm 17.9)$, the earliest treatment was 6 hours after injury, and the latest, 76 hours after the accident. Most fractures were type III (70.3\%) of Gustillo classification, this one being the most serious type. Considering the Tscherne classification for soft tissue injury, the distribution showed a higher concentration in groups II and III. Finally, using the AO classification of fractures, it is also observed that there was a prevalence of the most severe group (type C), and 19 fractures $(40.4 \%)$ were classified as being of this type. Thirty-two patients (39.5\%) were treated with immobilization, whereas 49 (60.49\%) were treated with some type of implant (internal/external fixation. Table 2 shows the other clinical and demographic characteristics and outcomes of the studied fractures.

Overall, it is observed that the rate of infection in the study sample was $23.7 \%$. Comparing the clinical and demographic variables and infection rate, we observed that infection was significantly more frequent in younger patients $(50 \%, p=0.011)$, and there is also a tendency to significant association $(p=0.08)$ with the origin patients, and those originating from the state country side had a higher prevalence of infection. (Table 3)

Table 4 indicates that the exposure time and soft tissue injury were significantly associated with infection. Patients with treatment delays greater than 24 hours had an infection rate of $34.3 \%$ against $9.1 \%$ among those treated within 24 hours $(p=0.012)$. Regarding to soft tissue injury, the most severe patients infected in $50 \%$ versus $1.3 \%$ in those mildly affected $(p=0.001)$. The Gustillo and AOrating, as well as the type of fixation showed no significant association with the infection outcome.

Table 1. Clinical and demographic characteristics of the studied population.

\begin{tabular}{|c|c|c|}
\hline Characteristics & $\begin{array}{c}\text { Frequency } \\
\text { (or mean } \pm \text { Standard deviation) }\end{array}$ & Proportion (\%) \\
\hline Age & $32,94 \pm 12,52$ & - \\
\hline \multicolumn{3}{|l|}{ Gender } \\
\hline Masculine & 68 & $83,95 \%$ \\
\hline Feminine & 13 & $16,05 \%$ \\
\hline \multicolumn{3}{|l|}{ Marital Status } \\
\hline Single & 49 & $60,49 \%$ \\
\hline Married & 27 & $33,33 \%$ \\
\hline Others & 5 & $6,17 \%$ \\
\hline \multicolumn{3}{|l|}{ Coming from } \\
\hline Salvador & 31 & $38,27 \%$ \\
\hline Country side & 33 & $40,74 \%$ \\
\hline Metropolitan region & 16 & $19,75 \%$ \\
\hline Other states & 1 & $1,23 \%$ \\
\hline \multicolumn{3}{|l|}{ Comorbidities } \\
\hline None & 31 & $38,27 \%$ \\
\hline Hypertension & 3 & $3,71 \%$ \\
\hline Smoking & 16 & $19,75 \%$ \\
\hline Alcoholism & 46 & $49,45 \%$ \\
\hline \multicolumn{3}{|l|}{ Site of Injury } \\
\hline Leg (tibia/fibula) & 39 & $48,15 \%$ \\
\hline Foot/ankle & 25 & $30,86 \%$ \\
\hline Forearm (radius/ulna) & 7 & $8,64 \%$ \\
\hline Other sites & 10 & $12,34 \%$ \\
\hline
\end{tabular}

Table 2. Orthopedic characteristics of the studied population

\begin{tabular}{|c|c|c|}
\hline Characteristics & Frequency & Proportion (\%) \\
\hline \multicolumn{3}{|c|}{ Time of exposure $(n=73)$} \\
\hline$\leq 12$ hours & 13 & $17,81 \%$ \\
\hline$\geq 12$ hours & 60 & $82,19 \%$ \\
\hline No information & 8 & \\
\hline \multicolumn{3}{|l|}{ Outcome (n=76) } \\
\hline No infection & 58 & $76.31 \%$ \\
\hline Infection & 18 & $23,68 \%$ \\
\hline No information & 5 & \\
\hline \multicolumn{3}{|c|}{ AO Classification $(n=47)$} \\
\hline Type A & 11 & $23,40 \%$ \\
\hline Type B & 17 & $36,17 \%$ \\
\hline Type C & 19 & $40,43 \%$ \\
\hline \multicolumn{3}{|l|}{$\begin{array}{l}\text { Gustillo Classification } \\
\qquad(n=64)\end{array}$} \\
\hline Type I & 2 & $3,12 \%$ \\
\hline Type II & 17 & $26,56 \%$ \\
\hline Type IIIA & 23 & $35,94 \%$ \\
\hline Type IIIB & 21 & $32,81 \%$ \\
\hline Type IIIC & 1 & $1,54 \%$ \\
\hline \multicolumn{3}{|c|}{$\begin{array}{l}\text { Tscherne Classification } \\
(n=65)\end{array}$} \\
\hline Grade I & 15 & $23,08 \%$ \\
\hline Grade II & 27 & $41,54 \%$ \\
\hline Grade III & 22 & $33,84 \%$ \\
\hline Grade IV & 1 & $1,54 \%$ \\
\hline \multicolumn{3}{|l|}{ Type of treatment (81) } \\
\hline External & 30 & $37,04 \%$ \\
\hline Internal & 19 & $23,45 \%$ \\
\hline Cast Immobilization & 32 & $39,51 \%$ \\
\hline
\end{tabular}

Table 3. Distribution of the outcome infection according to the clinical and demographic characteristics of the studied population.

\begin{tabular}{|c|c|c|c|}
\hline Characteristics & Infection $(n=18)$ & No infection $(\mathrm{n}=58)$ & $\mathbf{P}$ \\
\hline Age $(n=73)$ & & & 0,011 \\
\hline$\leq 40$ years old & 09 & 46 & \\
\hline$>40$ years old & 09 & 09 & \\
\hline Gender $(n=76)$ & & & 0,309 \\
\hline Masculine & 13 & 50 & \\
\hline Feminine & 05 & 08 & \\
\hline Marital status ( $n=71)$ & & & 0,612 \\
\hline Single & 11 & 34 & \\
\hline Married & 05 & 21 & \\
\hline Coming from $(n=76)$ & & & 0,083 \\
\hline $\begin{array}{c}\text { Capital and } \\
\text { metropolitan region }\end{array}$ & 07 & 36 & \\
\hline Country side & 11 & 22 & \\
\hline Site of infection $(n=76)$ & & & 0,138 \\
\hline Leg & 09 & 27 & \\
\hline Ankle and foot & 08 & 16 & \\
\hline Other sites & 01 & 15 & \\
\hline Smoking $(n=56)$ & & & 0,157 \\
\hline Yes & 01 & 14 & \\
\hline No & 12 & 29 & \\
\hline Alcoholism (n=76) & & & 0,235 \\
\hline Yes & 09 & 40 & \\
\hline No & 09 & 18 & \\
\hline
\end{tabular}




\begin{tabular}{|c|c|c|c|}
\hline Characteristics & Infection & No infection & $\mathbf{P}$ \\
\hline $\begin{array}{c}\text { Time of exposure } \\
(n=68)\end{array}$ & & & 0,012 \\
\hline$\leq 24$ hours & 03 & 30 & \\
\hline$>24$ hours & 12 & 23 & \\
\hline $\begin{array}{c}\text { Tscherne } \\
\text { classification }(n=62)\end{array}$ & & & 0,001 \\
\hline Grades I e II & 05 & 35 & \\
\hline Grades III e IV & 11 & 11 & \\
\hline $\begin{array}{c}\text { Gustillo } \\
\text { classification }(n=60)\end{array}$ & & & 0,193 \\
\hline Grades I e II & 02 & 16 & \\
\hline Grades III (A, B e C) & 13 & 29 & \\
\hline $\begin{array}{c}\text { AO Classification } \\
(n=51)\end{array}$ & & & 0,859 \\
\hline Type A & 02 & 09 & \\
\hline Type B & 03 & 14 & \\
\hline Type C & 06 & 19 & \\
\hline $\begin{array}{c}\text { Fixation Type } \\
(n=76)\end{array}$ & & & 0,530 \\
\hline External & 08 & 18 & \\
\hline Internal & 03 & 15 & \\
\hline Cast immobilization & 07 & 25 & \\
\hline
\end{tabular}

\section{DISCUSSION}

Data from this study allow tracing the epidemiological profile of patients who have suffered motorcycle accidents in the population studied. These individuals are usually young adults (32.9 years old), of the masculine gender (83.9\%), single (60.5\%), originating from the state country side $(40.7 \%)$, alcoholics (49.4 $\%)$, smokers (19.7\%) who mostly present as the major lesion leg fractures (48.2\%). The majority (82.2\%) had their initial procedure performed after 12 hours of injury, and $39.5 \%$ of cases were initially treated with immobilization after surgical debridement. Types IIIA and IIIB open tibial fractures were the most frequent (68.8\%); and there was a prevalence of fractures type $\mathrm{C}$, according to $\mathrm{AO}$ classification (40.4\%) and the grades I and II of parts damage were also prevalent in the sample (64.62\%). There was an overall infection rate of $23.7 \%$ in the sample studied. The infection outcome was associated with patient age, being more common in patients of 40 and older $(p=0.011)$; infection also prevailed when the time between trauma and the initial procedure took more than 24 hours $(p=0.012)$ and when soft tissue injury presented greater severity according to the classification of Tscherne $(p=0.001)$. There was no association with other variables studied, such as alcoholism and smoking, however, there was a trend to higher infection rate in patients originating from the state country side $(p=0.08)$.

Clinical and demographic data of the present study corroborated the study of Muller et al., ${ }^{7}$ who traced the profile of open fractures from a university hospital and also found that the majority of patients were male, married, and young, with mean age of 35.2 years old. Moore et al. ${ }^{14}$ in a similar study also found a mean age of 31 years old and male predominance (78.85\%). The mean duration of exposure found by Muller et al. ${ }^{7}$ was 5 hours and 39 minutes with $14.9 \%$ of injured starting treatment at over 6 hours after injury. Gustillo and Anderson ${ }^{12}$ found an average time of 4 hours and 24 minutes between the occurrence of early trauma and surgical treatment, $21.2 \%$ of the cases having been treated after over 6 hours. In the present study, we observed an average exposure time of 27.9 hours, which is much in disagreement with other studies. It is believed that this fact arises from the large number of patients in the state country side. The distance from the crash site, bureaucracy, waiting for exams, preparation for transportation and a vacant hospital bed on destination certainly influenced the prolonged exposure time.

The large presence of country side patients in our sample may be due to three main factors: high and increasing rate of motorcycle accidents in the less populated inner cities; the complexity of fractures requiring transfer to large hospitals; and finally, inadequate structure of hospitals in medium and small cities to assist patients with such traumas.

There was a high prevalence of patients who were classified as heavy drinkers. Arruda et al. ${ }^{15}$ found alcohol consumption in $12.9 \%$ of patients in the 6 hours prior to the trauma, reinforcing the idea that high alcohol intake could be directly associated to the cause of the motorcycle accidents. It should be emphasized, however, that in our study alcohol consumption was reported as a social condition of the individual, which does not mean alcohol intake at the time of the accident. Alcoholism, in our results, also showed no correlation to risk factors for infection. Types IIIA and IIIB open fractures from Gustillo classification were predominant in the sample (68.7\%), in accordance to other studies on open fractures. Arruda et al. ${ }^{15}$ found in their work $15.8 \%$ of injuries type I, 29.5\% type II and 54.6\% type III; Moore et al. ${ }^{14}$ found $3.7 \%$ type I, $44.2 \%$ type II and $50.9 \%$ type III.

The sample of this study revealed an overall infection rate of $23.7 \%$. This value is slightly higher than reported in similar studies on the subject. Muller et al.," ${ }^{7}$ for example, found a global percentage of $20.5 \%$ for acute infection in a patient sample. Longer exposure (high percentage of patients from the state country side) and more severe cases (according to the classification of Tscherne and Gustillo) may have been determining factors for superimposed infection in patients.

According to our data, the infection rate for patients with Gustillo fractures of type III was $30.9 \%$ (versus $11 \%$ of types I and II), while those classified as Tscherne III or IV (more severe) was $50 \%$ (versus $14.3 \%$ of types I and II). However, infection was significantly associated with soft tissue injury and exposure time, while Gustilo classification showed only a trend to statistical significance $(p=0.19)$.

The infection outcome has proved to be a variable related to the severity of the fracture in many studies. Kathod et al.., ${ }^{16}$ for example, found an association between type of open fracture and infection, being $8.7 \%$ in type I, $10.9 \%$ in type II, $23.5 \%$ in type IIIA, 67 \% in type IIIB, and $62.5 \%$ in type IIIC. No reliable studies were found correlating the classification of the severity of soft tissue injury with infection outcome. In this sense, our study revealed in a pioneer way the strong relationship between the classification of Tscherne and the occurrence of infection $(p=0.001)$, being the most serious injuries those also more likely to infect.

Limitations of this study are those inherent to all designs that use data collected from medical records, such as reliability 
and incompleteness of information. Also some sub-analyzes did not have sufficient statistical power, given that the sample size, which was calculated only for the outcome infection. However, it should be pointed out that the study presents relevant sampling and it is one of the few published studies on the topic, which specifically examines the epidemiology of fractures in motorcycle accidents and its most important clinical outcome.

\section{CONCLUSION}

Patients with open fractures caused by motorcycle accidents are mostly male, young, single, from the Capital city and metropolitan area. There was prevalence of serious injuries which affected most frequently the legs. Infection occurred in $23.7 \%$ of cases and was associated with age, duration of exposure and injury severity.

\section{REFERENCES}

1. de Oliveira NL, de Sousa RM. Injury diagnosis quality of life among motorcyclists, victims of traffic accidents. Rev Lat Am Enfermagem. 2003;11(6):749-56.

2. Pires AB, Vasconcellos EA, Silva AC. Transporte humano: cidades com qualidade de vida. São Paulo: Associação Nacional de Transportes Públicos; 1997.

3. Santos AMR, Moura MEB, Nunes BMV, Leal CFS, Teles JBM. Perfil das vítimas de trauma por acidente de motos atendidas em um serviço público de emergência. Cad Saúde Pública. 2008;24(8):1927-38.

4. Secretaria de Políticas de Saúde. Ministério da Saúde. Programa de Redução da Morbimortalidade por Acidentes de Trânsito: Mobilizando a Sociedade e Promovendo a Saúde. Rev Saúde Pública. 2000;36(1):114-7.

5. Krause RG, Franco JS. Cartilha de trânsito: dicas para você viver mais e melhor! São Paulo: Sociedade Brasileira de Ortopedia e Traumatologia. Disponível em http://bvsms.saude.gov.br/bvs/publicacoes/cartilha transito. pdf (Acessado em 20 de Junho de 2013).

6. Cunha FM, Braga GF, Drumond Junior SN, Figueiredo CTO. Epidemiologia de 1.212 fraturas expostas. Rev Bras Ortop. 1998;33(6):451-6.

7. Müller SS, Sadenberg T, Pereira GJC, Sadatsune T, Kimura EE, Novelli Filho JLVB. Estudo epidemiológico, clínico e microbiológico prospectivo de pacientes portadores de fraturas expostas atendidos em hospital universitário. Acta Ortop Bras. 2003;11(3):158-69.

8. Marin L, Queiroz MS. A atualidade dos acidentes de trânsito na era da velo- cidade: uma visão geral. Cad Saúde Pública. 2000;16(1):7-21.

9. Willenegger $\mathrm{H}$, Roth $\mathrm{B}$. Treatment tactics and late results in early infection following osteosynthesis. Unfallchirurgie. 1986;12(5):241-6.

10. Garner JS. CDC guideline for prevention of surgical wound infection. Infect Control. 1985; 7:190-200

11. Oestern HJ, Tscherne H. Pathophisiology and classification of soft tissue injuries associated with fractures. In: Tscherne $\mathrm{H}$, Gotzen L, editors. Fractures with soft tissue injuries. Berlin: Springer-Verlag; 1984. p.1-8.

12. Gustilo RB, Anderson JT. Prevention of infection in the treatment of one thousand and twenty-five open fractures of long bones: retrospective and prospective analyses. J Bone Joint Surg Am. 1976;58(4):453-8.

13. Müller ME, Nazarian S, Koch P, Schatzker J. The comprehensive classification of fractures of long bones. Berlin: Springer-Verlag; 1990.

14. Moore TJ, Mauney C, Barron J. The use of quantitative bacterial counts in open fractures. Clin Orthop Relat Res. 1989;(248):227-30.

15. Arruda LRP, Silva MAC, Malerba FG, Turibio FM, Fernandes MC, Matsumoto $\mathrm{MH}$. Fraturas expostas: estudo epidemiológico e descritivo. Acta Ortop Bras. 2009:17(6):326-30.

16. Khatod M, Botte MJ, Hoyt DB, Meyer RS, Smith JM, Akeson WH. Outcomes in open tibia fractures: relationship between delay in treatment and infection. J Trauma.2003:55(5):949-54 